https://doi.org/10.25143/socr.18.2020.3.043-048

\title{
Types of Human Health
}

\author{
Dr. iur. Lïga Mazure \\ Rezekne Academy of Technologies, Latvia \\ liga.mazure@inbox.lv
}

\section{Abstract}

WHO has significantly contributed to the modern legal definition of human health by providing a definition of health. This definition of health acquired a binding nature, becoming the content of national rules and regulations.

WHO's definition of health indirectly covers the types of human health. Although this definition of health was appraised as an innovative view of the understanding of human health, still nowadays it does not correspond to the stage of development of society.

Nowadays it is an expansion of the understanding of health as a nonmaterial good. A more detailed system of the types of human health can be created and legally recorded according to several division criteria.

Keywords: division criteria, health, human, types.

The World Health Organisation (hereinafter - WHO) has significantly contributed to the modern legal definition of human health. Soon after WWII, WHO defined health in its constitution as "a state of complete physical, mental and social well-being", also specifying that health is "not merely the absence of disease or infirmity" [29]. This definition was later reiterated [30]. Considering that this definition of health was not legally binding, countries have borrowed it and included in their national laws and regulations $[2 ; 10 ; 15]$. Thus, this definition of health acquired a binding nature, becoming the content of national laws and regulations.

This definition of health indirectly covers the types of human health. In fact, the physical, mental, and social health of a human being follows from the elements of the definition of human health. Although WHO's definition of health was seen as an innovative view of the understanding of human health, still nowadays it does not correspond to the stage of development of society. Legal arguments have been found that call for improvement of the legal definition of human health $[12 ; 13]$, as well as for creation of a more detailed system of the types of human health according to different division criteria. 
Firstly, according to the moment health is determined, health is divided into presumed, actual, and expected human health. It is assumed that each person has complete health until proven otherwise, similar to the presumption of competency [14, 79; $27 ; 28]$. Upon the patient's will or the initiative of the law, the doctor is obliged to check the patient's health $[9,6 ; 10,37$, Art. 1, Para. 2, Para. 38; 24, Para. 12], finding a specific level of health or actual health. From there it is possible to model the development of the person's health in the future, which needs to be done as soon as possible $[1,1 ; 7$, $614 ; 25,383$. Moreover, health can be expected both for the individual and their next generation, exceeding the limit of the person's lifespan, creating the expectancy levels of human health. It can be concluded that a determination sequence exists for these three types of human health - at first health is presumed where such presumption can be refuted by determining actual health, and health can also be expected using actual health as the point of reference.

Determining these three types of health is important in legal relationships. For example, the legal consequences of the person's actions depend on their actual health; expected health, similar to expected disability [8, Art. 1, Para. 6, Art. 4, Section 1, Para. 1], allows taking timely measures $[6,3]$ in order to decrease or prevent possible negative consequences for the person's health.

Secondly, according to the possibility to correct health, there is reversible health, where the disorder can be decreased or eliminated, and irreversible health where the condition cannot be improved and stays permanent or worsens. For example, for a long time (i.e., 1996-2011) a person with an amputated leg was required to undergo a second disability assessment, without the possibility to determine a lifelong disability from the beginning [8, Art. 8, Section 2, Para. 2; 18, Para. 13; 20, Para. 13]. Although medicine is developing and new options for treatment and health correction are created, there are still situations where corresponding regulations need to consider the reversible or irreversible nature of human health at a specific stage of development of society.

Thirdly, according to the development trend, health can be divided into three types: a) no change, which is a constant flat curve; b) upward trend, which is an improving curve; c) downward trend, which is a worsening curve. It is important to determine these types of health, for example, when qualifying for the controversial granting of state-funded medication. No universal priority criteria have been designed at the international level for distributing the state funding available when ensuring the person's right to health, generally leaving it at the discretion of each country and determining the main principle - distribution of funding must be appropriate, i.e. balancing separate individual rights with the interests of all society [5, Para. 57; 22, Para. 12; 23, Para. 12.1.3; 26]. The Latvian legal system contains three criteria for distribution of state funding in medical treatment - therapeutic effect, cost as an economic criterion, lifespan, i.e. to what degree particular medication extends life in comparison to other treatments available for the disease [9, Art. 5, Section 1, Para. 1, Art. 5, Section 6; 17, 3, Para. 4; 21, Para. 11.1; 22, Para. 17.2; 23, Para. 12.2]. When assessing the sensitive criteria of effect and lifespan, 
the patient's actual or possible health development trend while on medication is considered, i.e. no change, improving, or worsening.

Next, according to the nature of origin, human health can be: a) inherent, where permanent adequate or inadequate health is determined for the person after birth; b) acquired, where inadequate health determined for the person after birth is improved to the required level; c) restored, where the person's health is improved by decreasing or eliminating the disorders acquired in their lifetime. Such change in human health needs to be taken into account, for example, in order to choose the most suitable treatment for the individual patient, where the patient's self-care also means caring for others as a social responsibility $[1,1 ; 4,55 ; 16,162]$; in order to find out the reason for the change in health and the patient's role in it, where the patient's irresponsible and harmful actions can have negative consequences (a note of the patient's violation of the treatment regimen is made in the certificate of incapacity for work [19, Para. 17]; the doctor's refusal to treat the patient if the patient is not fulfilling their obligations during treatment [10, Art. 42]). Thus, the individual health development trend of a particular person, which is reflected in the patient's medical chart, and the reasons for it are important for providing appropriate treatment for the patient and achieving a desired treatment outcome.

Further on, health is the base of the person's actions with different possible stages of escalation while the person is implementing their capacities $[13,339]$. Through the interaction of medical and social criteria $[3,15 ; 11,282]$, the person can implement their capacities in two ways - internally, i.e. the capacity to perform the living function and medically related bodily and mental functions; and externally, i.e. the capacity for socialisation and personal fulfilment. Thus, according to the way of implementation, human health can be divided into internal and external health accordingly.

\section{Conclusions}

1. Nowadays it is the expansion of the understanding of health as a nonmaterial good. A more detailed system of the types of human health can be created and legally recorded according to different division criteria. It is noteworthy that indirect and fragmentary developments of these types of human health are already found in the rules and regulations as well as in the legal and medical practice.

2. The following types of human health can be singled out according to the following division criteria:

1) according to the moment health is determined: presumed, actual, and expected;

2) according to the possibility to correct health: reversible and irreversible;

3) according to the development trend: no change, improving, and worsening;

4) according to the nature of origin: inherent, acquired, and restored;

5) according to the way of implementation: internal and external. 
Liga Mazure. Types of Human Health

Suggestions - complete the Medical Treatment Law with Section $3^{1}$ as follows:

"Section $3^{1}$. (1) Complete health is assumed for each patient until actual health is determined for the particular patient, the future development of which is expected.

(2) In reversible health of a patient, the disorders can be decreased or eliminated; whereas in irreversible health the condition is permanent or worsens.

(3) Patient health can be constant or have an upward trend, if it is improving, or a downward trend, if it is worsening.

(4) The health condition determined for the patient after birth is their inherent health, where the patient can acquire health by decreasing or eliminating the disorders found at birth and where the patient can restore their health by decreasing or eliminating the disorders acquired in their lifetime.

(5) The patient's internal health means their bodily and mental capacities, whereas external health means the capacity for socialisation and personal fulfilment."

\section{Cilvēka veselības veidi}

\section{Kopsavilkums}

PVO ir devusi būtisku ieguldījumu cilvēka veselības tiesiskā definējuma formulēšanā, dodot veselības skaidrojumu. PVO veselības definējumā netieši ir ietverti arī cilvēka veselības veidi. Šis veselības definējums ir ieguvis saistošo raksturu, kḷ̂ustot par valstu normatīvā regulējuma saturu.

Lai arī šis veselības definējums savulaik bija vērtējams kā inovatīvs skatījums uz cilvēka veselības izpratni, tomēr tas vairs neatbilst mūsdienu sabiedrības attīstības pakāpei. Ir notikusi veselības kā nemantiskā labuma izpratnes paplašināšanās, tāpēc būtu jāizveido un tiesiski jānostiprina detalizētāka cilvēka veselības veidu sistēma pēc dažādiem dalījuma kritērijiem.

Lai normatīvajā regulējumā varētu iestrādāt piedāvātās idejas, ir nepieciešams papildināt Ārstniecības likumu ar $3^{1}$. pantu šādā redakcijā:

“31. pants. (1) Pacients tiek uzskatīts par pilnīgi veselu līdz brīdim, kad tiek konstatēts vinna faktiskais veselības stāvoklis un tā turpmākā attīstība ir paredzama.

(2) Pacienta atgriezeniskā veselība nozīmē, ka pastāv iespēja mazināt vai novērst veselības traucējumus; turpretim neatgriezeniskā veselība nozīmē, ka veselības stāvoklis ir nemainīgs vai tas pasliktinās.

(3) Pacienta veselība var būt nemainīga vai augšupejoša, ja tā uzlabojas, vai lejupejoša, ja pasliktinās.

(4) Pacientam pēc dzimšanas konstatētais veselības stāvoklis ir viṇam sākotnēji piemītošā veselība. Pacients var uzlabot to, mazinot vai novēršot pēc dzimšanas konstatētos veselības traucējumus, kā arī atjaunot to, mazinot vai novēršot dzives laikā iegūtos veselības traucējumus.

(5) Ar pacienta iekšējo veselību saprot viṇa ḳermeniskās un garīgās spējas, turpretim ar ārējo veselību - spēju socializēties un gūt personīgo piepildījumu."

Atslēgvārdi: cilvēka veselïba, veselïbas veidi. 
Liga Mazure. Types of Human Health

\section{Literature}

1. Australian Institute of Health and Welfare. 2014. Australia's Health 2014 (Nr. 14, AUS 178) (Canberra: AIHW).

2. Department of Veterans affairs act. 28.08.1990. Veterans Health Care Regulations (SOR/90-594): Law of Canada. Retrieved from: https://laws-lois.justice.gc.ca/eng/regulations/SOR-90-594/ page-1.html?txthl=definition+health\#s-2 [accessed on 05.04.2020.].

3. Murphy, D., "Concepts of Disease and Health", in The Stanford Encyclopedia of Philosophy (Summer 2020 Edition), Edward N. Zalta (ed.). Retrieved from: https://plato.stanford.edu/archives/sum2020/entries/health-disease/.

4. Jackson, E., Medical law: text, cases, and materials (Oxford: Oxford University Press, 2013).

5. Advocate General Bot, Y. 09.09.2008. Conclusions in the Case: Hartlauer Handelsgesellschaft $\mathrm{mbH}$ v. Wiener Landesregierung un Oberösterreichische Landesregierung. Retrieved from: http:// eur-lex.europa.eu/LexUriServ/LexUriServ.do?uri=CELEX:62007C0169:LV:HTML [accessed on 05.04.2020.].

6. Badash, I., et al., "Redefining health: The evolution of health ideas from Antiquity to the Era of Value-Based care", Cureus 9(2) (2017): 4, doi:10.7759/cureus.1018.

7. McHale, J. V., Fox, M., Murphy, J., Health Care Law: Text, Cases and Materials (London: Sweet \& Maxwell, 1997).

8. Invaliditātes likums: 09.06.2010. Latvijas Republikas likums. Latvijas Vēstnesis (Eng. The Republic of Latvia. 09.06.2010 Disability Law: Law of the Republic of Latvia).

9. Pacientu tiesību likums: 30.12.2009. Latvijas Republikas likums. Latvijas Vēstnesis (Eng. The Republic of Latvia. 12.30.2009 Patients' Rights Law: Law of the Republic of Latvia).

10. Ārstniecības likums: 01.07.1997. Latvijas Republikas likums. Latvijas Vēstnesis (Eng. The Republic of Latvia. 7.1.1997 Medical Treatment Law: Law of the Republic of Latvia).

11. Nordenfelt, L., "Health and disease: two philosophical perspectives," Journal of Epidemiology and Community Health 41 (1986): 281-284, doi:10.1136/jech.40.4.281.

12. Mazure, L., (in publishing) "Historical development of the legal interpretation of human health". In Proceedings of the 61st International Scientific Conference of Daugavpils University, Part B Social Sciences (Daugavpils: Daugavpils University).

13. Mazure, L., "Modern legal definition of human health" in Society. Integration. Education: Proceedings of the International Scientific Conference (May 22-23, 2020), Vol. VI (Rezekne: RTA, 2020), 334-343, doi:http://dx.doi.org/10.17770/sie2020vol6.4912.

14. Mazure, L., "Pacienta griba un tās civiltiesiskā aizsardzība (Eng. The patient's will and its civil protection)" (Rēzekne: RA Izdevniecība, 2014).

15. Habersack, M., Luschin, G., "WHO-definition of health must be enforced by national law: a debate," BMC Med Ethics 14 (2013): 24, doi:10.1186/1472-6939-14-24.

16. Büchs M., Koch M., "Challenges for the degrowth transition: The debate about wellbeing", Futures 105 (2019): 155-165, doi:10.1016/j.futures.2018.09.002.

17. Ministru Kabinets. 09.11.2006. Ambulatorajai ārstēšanai paredzēto zāḷu un medicīnisko ierīču iegādes izdevumu kompensācijas kārtība: MK noteikumi Nr. 899 (Eng. The Cabinet of Ministers. 9.9.2006 Procedure for Compensation of Expenses for the Purchase of Medicines and Medical Devices Intended for Outpatient Treatment: Cabinet Regulation No. 899). Latvijas Vēstnesis. 
Liga Mazure. Types of Human Health

18. Ministru Kabinets. 25.11.2003. Invaliditātes ekspertīzes kārtība Veselības un darbspēju ekspertīzes ārstu valsts komisijā: MK noteikumi Nr. 650 (Eng. The Cabinet of Ministers. 11.25.2003 Procedure for Disability Examination in the State Commission of Health and Working Ability Examination Doctors: Cabinet Regulation No. 650). Latvijas Vēstnesis.

19. Ministru Kabinets. 06.04.2001. Darbnespējas lapu izsniegšanas kārtība: MK noteikumi Nr. 152 (Eng. The Cabinet of Ministers. April 6, 2001 Procedure for Issuance of Incapacity for Work Certificates: Cabinet Regulation No. 152). Latvijas Vēstnesis.

20. Ministru Kabinets. 23.07.1996. Invaliditātes ekspertīzes kārtība Veselības un darbspēju ekspertīzes ārstu valsts komisijā: MK noteikumi Nr. 263 (Eng. The Cabinet of Ministers. 7.23.1996 Procedure for Disability Examination in the State Commission of Health and Working Ability Examination Doctors: Cabinet Regulation No. 263). Latvijas Vēstnesis.

21. Satversmes tiesa. 28.06.2013. Spriedums (2012-26-03), Latvijas Republika (Eng. The Constitutional Court. 28.6.2013. Judgment (2012-26-03), Republic of Latvia). Retrieved from: www.satv.tiesa. gov.lv [accessed on 05.04.2020.].

22. Satversmes tiesa. 09.04.2013. Spriedums (2012-14-03), Latvijas Republika (Eng. The Constitutional Court. 4.4.2013 Judgment (2012-26-03), Republic of Latvia). Retrieved from: www.satv.tiesa.gov.lv [accessed on 05.04.2020.].

23. Satversmes tiesa. 29.12.2008. Spriedums (2008-37-03), Latvijas Republika (Eng. The Constitutional Court. 29.12.2008. Judgment (2012-26-03), Republic of Latvia). Latvijas Vēstnesis, 30.12.2008., 202.

24. Senāta Administratīvo lietu departments. 24.03.2020. Spriedums (SKA-790/2020), Latvijas Republika (Eng. Department of Administrative Cases of the Senate. 24.3.2020. Judgment (SKA-790/2020), Republic of Latvia). Retrieved from: www.at.gov.lv [accessed on 05.04.2020.].

25. Pattinson S., "Medical Law \& Ethics", $1^{\text {st }}$ edit. (London: Sweet \& Maxwell, 2006).

26. Annus T., "The Right to Health Protection in the Estonian Constitution”, Juridica International: Law Review of University of Tartu, Vol. 7, I (2002).

27. The House of Assembly. 1989. Hospitals Act (RSNS 1989, c 208): Law of Nova Scotia, Canada. Retrieved from: http://canlii.ca/t/52pkf [accessed on 05.04.2020.].

28. The Supreme Court of Nova Scotia. 08.11.2007. The Judgment (Crewe (Re), 2007 NSSC 322), Canada. Retrieved from: https://www.canlii.org/en/ns/nssc/doc/2007/2007nssc322/2007nssc322. html [accessed on 05.04.2020.].

29. World Health Organization. 22.07.1946. Constitution of the World Health Organization. Preamble. Retrieved from: https://www.who.int/governance/eb/who_constitution_en.pdf [accessed on 05.04.2020.].

30. World Health Organization. 21.11.1986. The Ottawa Charter for Health Promotion. First International Conference on Health Promotion, Ottawa. Retrieved from: https://www.who. int/healthpromotion/conferences/previous/ottawa/en/ [accessed on. 05.04.2020.]. 